\title{
AZ ÉNEK-ZENE TANTÁRGYAT TANÍTÓ PEDAGÓGUSOK TANÍTÁSRÓL ALKOTOTT NÉZETEI
}

\author{
ASZTALOS ANDREA \\ ELTE PPK Neveléstudományi Doktori Iskola \\ SZTE JGYPK Müvészeti Intézet, Ének-Zene Tanszék
}

\begin{abstract}
A tanulmány célja feltárni és bemutatni a nyolcosztályos általános iskolában énekzene tantárgyat oktató pedagógusok nézeteit a tanítással kapcsolatosan. A vizsgálatban 176 alsó tagozatos tanító és 272 ének-zene szakos tanár vett részt. Az adatfelvétel online kérdőíves módszerrel történt. Az adatok kvantitatív módszerekkel való feldolgozásához az SPSS24 programot használtuk. A pedagóguscsoportok tanulásszervezési eljárásokkal, alkalmazott információforrásokkal és módszerekkel kapcsolatos nézeteik között több különbséget is feltártunk. Összefüggést találtunk a pedagógusok életkora, képzettsége, a pályán eltöltött gyakorlata és a tanításról alkotott nézeteik között.
\end{abstract}

Kulcsszavakः ének-zene tanári nézetek, tanítás, tanulásszervezési eljárások, tanítási módszerek

The purpose of this paper is to reveal and present primary teachers' and classroom music teachers' beliefs about teaching. In the study, 176 primary teachers and 272 classroom music teachers participated. The research method employed was an online questionnaire. Data were analyzed using quantitative analysis protocols with SPSS24 program. We revealed differences between the teachers' groups' beliefs about learning organization process, applied information sources and teaching methods. We found correlations between the age, qualifications and practice of teachers and their beliefs about teaching.

Keywords¥ music teachers’ beliefs, teaching, learning organization process, teaching methods

Levelező szerző: Asztalos Andrea, SZTE JGYPK Művészeti Intézet, Ének-Zene Tanszék,

6725 Szeged, Hattyas u. 10. E-mail: asztalos.andrea@jgypk.szte.hu 


\section{Bevezetés}

köznapi szóhasználatban az oktatás és a tanítás szinonimaként fordul elő. Az oktatás a hétköznapi értelmezés szerint valamely információ, ismeret, tudás megtanítása, kezelése, elsajátíttatása. A szaknyelv viszont megkülönbözteti ezt a két fontos fogalmat.

"Az oktatás olyan, a kultúra közvetítésében meghatározó szerepü komplex, tudatos, tervszerü, direkt és indirekt tevékenység, mely az ismeretszerzésnek, a jártasságok, a készségek kiépítésének, a gondolkodási funkcióknak, attitüdöknek, képességeknek, magatartás-, meggyőződésformálásnak az alapvető eszköze, s legfontosabb törekvése az önszabályozó tanulás kialakítása. Azt a célirányos tevékenységet, mely a tanulás feltételeinek a megteremtését biztosítja, hívjuk tanításnak." (Rétby 2003.)

\section{Szakirodalmi háttér}

\section{A pedagógusok nézeteinek kutatása}

A 90-es évek végén született pedagóguskutatások a nézeteknek, a gyakorlati tudásnak és a cselekvéseknek komplex kapcsolatát feltételezik, s úgy vélik, hogy a gyakorlatban a gondolkodás és a cselekvés komplex egységet alkot, a nézetek és a tevékenység között interaktív kapcsolat van. A nézetek és a gondolkodás mozgatja a cselekvést, ugyanakkor a tapasztalatok, a cselekvéssel kapcsolatos reflexiók megváltoztatják, kiegészítik a nézeteket (Richardson 1996).

A nézetek és a gyakorlati tevékenységek közötti közvetlen kapcsolatból kifolyólag a tanárok nézeteinek tanulmányozása fontos témává vált az oktatáskutatás területén (Ernest 1989; Fives-Buebl 2008; Kagan 1992; Nespor 1987; Pajares 1992; Raths 2001; Richardson 1996; Thompson 2007; Vartuli 2005). A tanári nézeteket általában a tanárjelölteknek és a tanároknak a tanulókról, tanulásról, osztályról és a tanítandó tananyagról alkotott implicit feltevéseiként definiálják (Kagan 1992). A tanároknak a tanításról, tanulásról és a tanítási anyagról alkotott nézeteinek közvetlen hatásuk van arra, hogy milyen tanítási módszert alkalmaznak és hogyan tanítanak az osztályban, amelyek pedig befolyásolják a tanulók tanulási tapasztalatait (Ernest 1989). Thompson (2007) megállapította, hogy a tanárok nézetei és osztálytermi cselekedetei nem választhatók el egymástól. A tanárok nézeteinek nyilvánvaló hatásuk van a döntéseikre és a viselkedésükre, de ezek gyakran implicitek, melyek a tanárok cselekedeteire anélkül hatnak, hogy ezeknek a nézeteknek valójában a tudatában lennének (Ernest 1989; Vartuli 2005).

\section{Az ének-zene tanárok tanitásról alkotott nézetei}

Számos kutatás során bebizonyosodott, hogy az ének-zene tanárok zenetanítás céljairól alkotott nézetei kapcsolatban vannak, összefüggést mutatnak a zenei képességről alkotott nézeteikkel.

Rasor (1988) vizsgálatában rámutatott arra, hogy az ének-zene tanárok 75\%-a az általános ismeretek átadását, 49\%-a az élménynyújtást és a müvészetközvetítést tartja az általános iskolai ének-zene oktatás legfontosabb céljának. Mindössze az ének-zene tanárok 20\%-a gondolja úgy, hogy fel kellene készíteni a gyerekeket a zenei élmények 
befogadására és csak $15 \%$ vélte úgy, hogy a zenei müveltség és a kreativitás az ének-zene oktatás célja. Rasor azt feltételezi, hogy a zenei nevelés céljáról alkotott nézetek hatással vannak a tanulók tanulási képességeire. Azonban Rasor nem vizsgálta azokat a módszereket, amelyekkel ezek a nézetek összefüggnének más nézetekkel vagy az osztálytermi tanítási gyakorlattal.

Carter (1986) kutatásai során rávilágított arra, hogy az ének-zene tanárok szerint az ének-zene tanítás három legfontosabb célja: 1) A zene megszerettetése, 2) A zenei müveltség fejlesztése, annak érdekében, hogy a diákok élethosszig tartó zenei élményben vehessenek részt, 3) Olyan tanulási környezet létrehozása, amely nemcsak a tehetségesek fejlődését segíti, hanem fejleszteni fogja minden diák esztétikai zenei érzékenységét. Ezek az eredmények utalnak a zenei képességről alkotott tanári nézetek és az általános iskolai zenei nevelés közötti kapcsolatra.

Tudomásunk szerint Magyarországon még eddig nem folyt olyan kutatás, amely kizárólag az ének-zene tantárgyat tanító pedagógusok gondolkodását vizsgálta volna a tanítással kapcsolatban, így ebben a témában végeztünk vizsgálatokat 2017-ben, amelyeket a továbbiakban részletezünk.

\section{A kutatás célja, mintavétel}

A kutatásunk célja feltárni és bemutatni a nyolcosztályos általános iskolában ének-zene tantárgyat oktató pedagógusok nézeteit a tanítással kapcsolatosan. Vizsgáltuk a tanítók és az ének-zene tanárok gondolkodásában megjelenő különbségeket, hasonlóságokat és az összefüggéseket a pedagógusnézetek és más változók - életkor, képzettség, gyakorlat - között.

A kérdőíves kutatáshoz az egyszerü véletlen mintavételi eljárást alkalmaztuk. A vizsgálati alapsokaságot a Magyarországon nyolcosztályos általános iskolában ének-zene tantárgyat tanító pedagógusok alkotják. A kutatás mintáját a magyarországi nyolc évfolyamos általános iskolák 15\%-a adja. Az online kérdőívet 448 ének-zene tantárgyat tanító pedagógus töltötte ki, akik nyolcosztályos általános iskolában tanítanak Magyarországon. A kutatásban 176 alsó tagozatos tanító és 272 ének-zene szakos tanár vett részt.

$\mathrm{A} z$ adatfelvétel online kérdőíves módszerrel történt. Az adatok kvantitatív módszerekkel való feldolgozásához az SPSS24 programot használtuk, mellyel leíró statisztikákat készítettünk és összefüggésvizsgálatokat folytattunk le ANOVA varianciaanalízissel.

\section{A kutatás eredményei}

A kutatásunkban vizsgáltuk az ének-zene tantárgyat tanító pedagógusok gondolkodását a tanulásszervezési eljárásokkal, módszerekkel; a tanítás során alkalmazott információforrásokkal és a tanítás során használt módszerekkel, eszközökkel kapcsolatosan.

\section{A pedagógusok gondolkodása a tanulásszervezési eljárásokkal, módszerekkel kapcsolatosan}

$\mathrm{A} z$ általunk vizsgált pedagóguscsoportok (tanítók és ének-zene tanárok) által használt tanulásszervezési eljárások, módszerek, eszközök alkalmazási gyakoriságának átlag- 


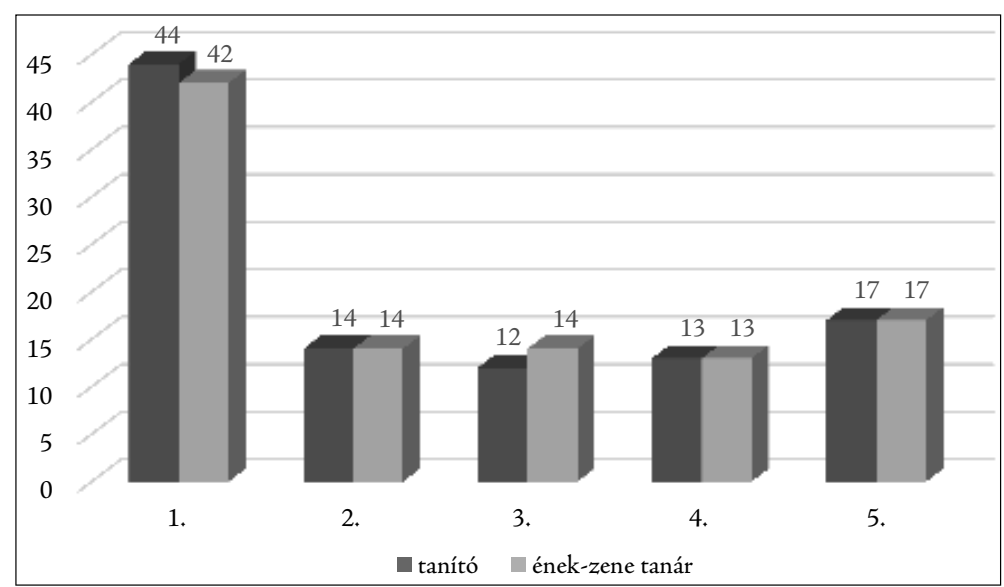

1. ábra: A pedagóguscsoportok által alkalmazott tanulásszervezési eljárások százalékos eloszlásai. (Megjegyzés: A fenti ábrán szereplő tanulásszervezési eljárások: 1. Frontális osztálytermi foglalkozás; 2. Páros tanulói munka;3.Különböző, nem kifejezetten kooperatív típusú csoportmunkák; 4. Különféle kooperatív tanulásszervezési eljárások; 5. Önáló tanulói munka, személyre szabott feladatokkal)

értékeit vizsgáltuk, melyek alapján megállapítható, hogy a mintánkban szereplő tanítók 44\%-ban, az ének-zene tanárok 42\%-ban frontális osztálytermi foglalkozás keretében szervezik a munkát a tanításuk során. Páros munkát az általunk vizsgált pedagóguscsoportok 14\%-ban alkalmaznak a tanórákon. Különböző, nem kifejezetten kooperatív típusú csoportmunkák a tanítók szerint $12 \%$-ban, míg az ének-zene tanárok vélekedése alapján 14\%-ban van jelen a tanítási órákon. Kooperatív tanulásszervezési eljárásokat átlagosan 13\%-ban használnak az ének-zenét tanító pedagógusok. Önálló tanulói munka megjelenése az ének-zene órákon a tanítók és a tanárok gyakorlatában egyaránt átlagosan 17\%-ban van jelen. Összességében megállapíthatjuk, hogy elenyésző (1-2\%-os), nem szignifikáns eltérés van a különböző pedagóguscsoportok nézetei között, melyek a tanulásszervezési eljárások, módszerek tanórákon történő alkalmazásának gyakoriságával kapcsolatosak (1. ábra).

A mintánkban szereplő alsós tanítók szerint a tanulásszervezési eljárásokat a legnagyobb mértékben a pedagógusok saját személyisége, míg az ének-zene tanárok vélekedése szerint az adott tanítási óra célja határozza meg. Ugyanakkor a pedagógusok egyöntetűen úgy gondolják, hogy legkevésbé a szülők elvárásai vannak hatással a tanulásszervezési eljárások kiválasztására. Befolyásolja a tanulásszervezési eljárások alkalmazását a tanulócsoport aktuális állapota, a pedagógus saját személyisége, a tanulócsoport összetétele és a pedagógus-továbbképzéseken tanultak is. Nagy mértékủ különbséget tártunk fel az általunk vizsgált pedagóguscsoportok gondolkodásában az alábbi tanulásszervezési eljárások alkalmazását befolyásoló tényezőket tekintve:

- Az adott tanítási óra céljai

- A pedagógus személyisége

- A szülők elvárásai

- Az országos kompetenciamérés helyi eredményei

- A szaktanácsadó tanácsai

- Az életpályamodellhez kapcsolódó pedagógusminősítés (várható) elvárásai

- Kutatási eredmények alapján bizonyítottan bevált módszerek 
Míg az ének-zene tanárok esetében erősebben befolyásolja a tanulásszervezési eljárások alkalmazását a tanítási óra célja, addig a tanítóknál meghatározóbb szerepe van a pedagógus saját személyiségének. A szülők elvárásai és a szaktanácsadó tanácsai az ének-zene tanárok számára kevésbé befolyásoló tényezők, mint a tanítóknál.

A tanítók és az ének-zene tanárok gondolkodása közti szignifikáns különbség megállapítása érdekében egyszempontú varianciaanalízist alkalmaztunk, melynek eredményeképpen négy tényező esetében van szignifikáns különbség a tanítók és az ének-zene tanárok nézetei között. Az adott tanítási óra céljai $(p=0,042)$, a pedagógus saját személyisége $(p=0,002)$, a szülők elvárásai $(p=0,032)$, a szaktanácsadó tanácsai $(p=0,029)$ mind olyan tényezők, melyek eltérő mértékben befolyásolják a tanítókat és az ének-zene tanárokat a tanulásszervezési eljárások, módszerek megválasztásában.

\section{A pedagógusok gondolkodása a tanitás során alkalmazott információforrásokkal kapcsolatosan}

Az általunk megkérdezett pedagógusok szerint a tanórákon leggyakrabban alkalmazott információforrás a tankönyv és munkafüzet, a legkevésbé pedig az online közösségi oldalak.

A $z$ ének-zene tanárok és az alsó tagozaton ének-zene tantárgyat oktató tanítók a tanítás során alkalmazott információforrások gyakoriságával kapcsolatos gondolkodása között is eltérések figyelhetők meg néhány esetben, melyeket az átlag-, és szórásértékek mutatnak. Ezek alapján különbség fedezhető fel a két pedagóguscsoport gondolkodásában a komplex digitális tananyagok, az online közösségi oldalak, a könyvtárban/médiatárban rendelkezésre álló információforrások, az oktató célú hanganyagok tanórai alkalmazását illetően. A tankönyv, munkafüzet; az internet; a saját készítésű szemléltető eszközök, feladatlapok; az oktató célú képek, animációk, filmek; a tanulói tevékenység során szerzett tapasztalatok, élmények tanórába való beépítését, tanórai alkalmazását tekintve nincs számottevő különbség a tanítók és az ének-zene tanárok gondolkodása között.

A pedagóguscsoportok nézetei közti szignifikáns különbség kimutatása érdekében egyszempontú varianciaanalízist alkalmaztunk. A vizsgálat eredményeképpen megállapítható, hogy a következő három esetben: 1$)$ az online közösségi oldalak ( $p=0,009)$; 2) a könyvtárban/médiatárban rendelkezésre álló információforrások $(p=0,020)$ és az 3) oktató célú hanganyagok tanórai alkalmazásával $(p=0,021)$ kapcsolatos vélekedések között van szignifikáns különbség a két pedagóguscsoport között. A komplex digitális tananyagok alkalmazását tekintve mégsincs szignifikáns különbség a tanítók és az énekzene tanárok vélekedése között.

\section{A pedagógusok gondolkodása a tanitás során alkalmazott módszerekkel, eszközökkel kapcsolatosan}

A tanórán leggyakrabban alkalmazott módszer a tanítók és a tanárok véleménye szerint egyaránt a magyarázat, viszont az átlagértékek között számottevő különbség észlelhető. Gyakran alkalmazott módszerek, eszközök közé tartozik a megbeszélés; szemléltetés, demonstráció; egyéni munka; internet és a tanítók esetében a játék. 
$\mathrm{A} z$ általunk vizsgált pedagóguscsoportok gondolkodása a tanórák során alkalmazott módszerek, eljárások, eszközök használata terén is eltérö. Az átlag- és szórásértékek jól mutatják, hogy a magyarázat; előadás; megbeszélés; tanulói kiselőadás; páros munka; önként vállalt önálló vagy csoportos tanulói kiselőadás; differenciálás; játék, szimuláció; interaktív tábla használata terén különbség van a pedagógusok vélekedés között, viszont arról nem adnak egyértelmű információt, hogy ez a különbség szignifikáns-e.

$\mathrm{Az}$ egyszempontú varianciaanalízis lefolytatását követően megállapíthatjuk, hogy a tanítók és az ének-zene tanárok gondolkodásában az alábbi tanítási módszerek és eszközök alkalmazási gyakoriságát tekintve van szignifikáns különbség: magyarázat ( $p=0,048)$; tanulói kiselőadás $(p=0,002)$; önként vállalt önálló vagy csoportos tanulói kiselőadás $(p=0,006)$; játék, szimuláció $(p=0,000)$. Ezt a különbséget a két pedagóguscsoport nézetei között az általuk tanítandó gyerekek korosztályi sajátosságai is okozhatják, hiszen a tanítók csak alsó tagozatos gyerekeket, míg az ének-zene tanárok nagyrészt felső tagozatos diákokat tanítanak.

\section{A tanitással kapcsolatos pedagógusnézetek összefüggései a tanitó/ének-zene tanár} életkorával, képzettségével és a szakmai gyakorlatával

A mintánkban szereplő tanítók és ének-zene tanárok tanulásszervezési eljárásokkal, módszerekkel; a tanítás során használt információforrásokkal és a tanítás során alkalmazott módszerekkel, eszközökkel kapcsolatban alkotott nézeteik és a pedagógusok életkora, képzettsége és szakmai gyakorlata közötti összefüggéseket vizsgáltuk, melyhez kereszttáblaelemzést és $\chi^{2}$-próbát végeztünk el. A tanítók életkora szignifikánsan befolyásolja a pedagógus személyiségének szerepét a tanulásszervezési eljárások kiválasztásában $(p=0,050)$, a komplex digitális tananyagok $(p=0,050)$ és az önként vállalt önálló vagy csoportos tanulói kiselőadás $(p=0,009)$ tanórai alkalmazásának gyakoriságában (1. táblázat).

1. táblázat: Az alsós tanítók életkora és a tanítással kapcsolatos nézeteik közötti összefüggések

\begin{tabular}{lcc}
\hline & \multicolumn{2}{c}{ Tanítók } \\
\cline { 2 - 3 } & Pearson-féle $\chi^{2}$ & Szign. \\
\hline Pedagógus személyisége - életkor & 15,537 & 0,050 \\
Komplex digitális tananyagok - életkor & 20,48 & 0,050 \\
Önként vállalt önálló vagy csoportos tanulói kiselőadás - életkor & 26,41 & 0,009 \\
\hline
\end{tabular}

Jelmagyarázat: Szign. = szignifikancia

A $z$ ének-zene tanárok életkora szignifikáns hatással van a különféle kooperatív tanítási eljárások $(p=0,043)$, a komplex digitális tananyagok $(p=0,015)$, az online közösségi oldalak $(p=0,028)$ és a játék, szimuláció $(p=0,009)$ alkalmazásának gyakoriságára. A z ének-zene tanárok életkora döntő hatással van arra, hogy a tanulócsoportok aktuális állapota $(p=0,002)$ és az adott tanítási óra célja $(p=0,045)$ milyen mértékben befolyásolja a tanórán alkalmazott tanulásszervezési eljárások kiválasztását (2. táblázat). 
2. táblázat: Az ének-zene tanárok életkora és a tanítással kapcsolatos nézeteik közötti összefüggések

\begin{tabular}{lcc} 
& \multicolumn{2}{c}{ Ének-zene tanárok } \\
\cline { 2 - 3 } & Pearson-féle $\chi^{2}$ & Szign. \\
\hline Különféle kooperatív tanítási eljárások- életkor & 194,22 & 0,043 \\
Tanulócsoport aktuális állapota - életkor & 20,959 & 0,002 \\
Adott tanítási óra célja - életkor & 17,26 & 0,045 \\
Komplex digitális tananyagok - életkor & 20,44 & 0,015 \\
Online közösségi oldal - életkor & 18,71 & 0,028 \\
Játék, szimuláció - életkor & 156,12 & 0,009 \\
\hline
\end{tabular}

Jelmagyarázat: Szign. = szignifikancia

A pedagógusok felsőfokú végzettsége, képzettsége is több ízben döntően befolyásoló hatással van a tanítással kapcsolatos gondolkodásukra. A pedagógusok képzettsége hatással van arra, hogy a tanulásszervezési eljárások kiválasztásában milyen mértékben van befolyásoló hatása a pedagógus személyiségének $(p=0,004)$ és a szülők elvárásainak $(p=0,006)$. Szignifikáns összefüggést találtunk a pedagógusok képzettsége és a tanórákon alkalmazott információforrások és módszerek, úgymint az online közösségi oldalak $(p=0,024)$, az előadás $(p=0,006)$, a tanulói kiselőadás $(p=0,018)$ és a játék, szimuláció $(p=0,001)$ alkalmazási gyakoriságával kapcsolatban (3. táblázat).

3. táblázat: Az ének-zene tantárgyat tanító pedagógusok képzettsége, felsőfokú iskolai végzettsége és a tanítással kapcsolatos nézeteik közötti összefüggések

\begin{tabular}{lcc}
\hline & \multicolumn{2}{c}{ Pedagógusok } \\
\cline { 2 - 3 } & Pearson-féle $\chi^{2}$ & Szign. \\
\hline Pedagógus személyisége - képzettség & 15,247 & 0,004 \\
Szülők elvárásai - képzettség & 17,988 & 0,006 \\
Online közösségi oldalak - képzettség & 14,522 & 0,024 \\
Előadás - képzettség & 18,079 & 0,006 \\
Tanulói kiselőadás - képzettség & 15,276 & 0,018 \\
Játék, szimuláció - képzettség & 22,829 & 0,001 \\
\hline
\end{tabular}

Jelmagyarázat: Szign. = szignifikancia

Végezetül vizsgáltuk, hogy van-e összefüggés a pedagógusok pályán eltöltött szakmai gyakorlata és a tanítással kapcsolatos nézeteik között. A tanítók pályán eltöltött gyakorlata döntő hatással van arra, hogy a tanulásszervezési eljárások kiválasztásakor a tanulócsoport aktuális állapota $(p=0,050)$ milyen mértékben számít meghatározó tényezőnek. Szignifikáns összefüggésre bukkantunk az önálló tanulói munka ( $p=$ $0,000)$, a komplex digitális tananyagok $(p=0,038)$ alkalmazási gyakorisága és az alsós tanítók pályán eltöltött szakmai gyakorlata között (4. táblázat). 
4, táblázat: Az alsós tanítók szakmai gyakorlata és a tanítással kapcsolatos nézeteik közötti összefüggések

\begin{tabular}{lcc}
\hline & \multicolumn{2}{c}{ Tanítók } \\
\cline { 2 - 3 } & Pearson-féle $\chi^{2}$ & Szign. \\
\hline Önálló tanulói munka, személyre szabott feladatokkal - gyakorlat & 529,070 & 0,000 \\
A tanulócsoport aktuális állapota - gyakorlat & 36,315 & 0,050 \\
Komplex digitális tananyagok - gyakorlat & 37,609 & 0,038 \\
\hline
\end{tabular}

Jelmagyarázat: Szign. = szignifikancia

Az ének-zene tanárok pályán eltöltött szakmai gyakorlata döntően, szignifikánsan befolyásolja azt, hogy milyen mértékben van hatással a tanulócsoport aktuális állapota $(p=0,000)$, az adott tanítási óra célja $(p=0,039)$ és a pedagógus-továbbképzéseken tanultak $(p=0,004)$ a tanulásszervezési eljárások kiválasztására. A tanárok gyakorlata és a páros tanulói munka ( $p=0,044)$; a szemléltetés, demonstráció $(p=0,000)$; az egyéni munka $(p=0,004)$; a differenciálás $(p=0,014)$ és a multimédia $(p=0,019)$ alkalmazási gyakorisága között szignifikáns összefüggést találtunk (5. táblázat).

5. táblázat: Az ének-zene tanárok szakmai gyakorlata és a tanítással kapcsolatos nézeteik közötti összefüggések

\begin{tabular}{lcc}
\hline & \multicolumn{2}{c}{ Ének-zene tanárok } \\
\cline { 2 - 3 } & Pearson-féle $\chi^{2}$ & Szign. \\
\hline Páros tanulói munka - gyakorlat & 407,168 & 0,044 \\
A tanulócsoport aktuális állapota - gyakorlat & 154,911 & 0,000 \\
Az adott tanítási óra célja - gyakorlat & 37,452 & 0,039 \\
A pedagógus-továbbképzéseken tanultak - gyakorlat & 46,624 & 0,004 \\
Szemléltetés, demonstráció - gyakorlat & 54,880 & 0,000 \\
Egyéni munka - gyakorlat & 45,983 & 0,004 \\
Differenciálás - gyakorlat & 41,774 & 0,014 \\
Multimédia - gyakorlat & 40,475 & 0,019 \\
\hline
\end{tabular}

Jelmagyarázat: Szign. = szignifikancia

\section{Konklúzió}

A nyolcosztályos általános iskolában tanító alsó tagozatos tanítók és ének-zene tanárok tanítással kapcsolatos gondolkodása között számos helyen szignifikáns különbséget találtunk, melyek hatással vannak a tanítási gyakorlatukra is. Míg az alsós tanítók szerint a tanulásszervezési eljárásokat a legnagyobb mértékben a pedagógus saját személyisége, addig az ének-zene tanárok vélekedése szerint az adott tanítási óra célja határozza meg. A $z$ adott tanítási óra céljai, a pedagógus saját személyisége, a szülők elvárásai, a szaktanácsadó tanácsai eltérő mértékben befolyásolják a tanítókat és az ének-zene tanárokat a tanulásszervezési eljárások, módszerek megválasztásában és egyben e téren szignifi- 
káns különbséget is mutatnak a két pedagóguscsoport nézetei között. Ezen felül számos szignifikáns különbséget tártunk fel a tanítók és az ének-zene tanárok által alkalmazott információforrások, módszerek, eljárások alkalmazásának gyakoriságát tekintve. Kutatásunk eredményeképpen bebizonyosodott, hogy a pedagógusok életkora, képzettsége és a pályán eltöltött gyakorlata döntő hatással van a tanítással kapcsolatos vélekedéseik nagy részére is.

\section{IRODALOM}

Carter, K. G. (1986) The Status of Vocal/General Music Programs in Oklahoma Elementary Schools. Doctoral Dissertation. The University of Oklahoma.

Ernest, P. (1989) The Impact of Beliefs on the Teaching of Mathematics. In: P. Ernest (ed.) Math Teaching: The State of the Art. New York, Falmer Press. pp. 249-254.

Fives, H. \& Buent, M. M. (2008) What Do Teachers Believe? Developing a Framework for Examining Beliefs about Teachers' Knowledge and Ability. Contemporary Educational Psychology, Vol. 33. No. 2. pp. 134-176.

Kagan, D. M. (1992) Implications of Research on Teacher Belief. Educational Psychologist, Vol. 27. No. 1. pp. 65-90.

Nespor, J. (1987) The Role of Beliefs in the Practice of Teaching. Journal of Curriculum Studies, Vol. 19. No. 4. pp. 317-328.

Pajares, M. F. (1992) Teacher's Beliefs and Educational Research: Cleaning up a Massy Construct. Review of Educational Research, Vol. 62. No. 3. pp. 307-332.

Rasor, S. H. (1988) A Study and Analysis of General Music Education, K-8, in the Public Schools of Ohio, 1987. PhD Dissertation. University of Cincinnati, ProQuest.

Raths, J. (2001) Teachers' Beliefs and Teaching Beliefs. Early Childhood Research E Practice, Vol. 3. No. 1. http://ecrp.illinois.edu/v3n1/raths.html

Réthy Endréné (2003) Oktatáselméleti irányzatok. In: Falus Iván (ed.): DidaktikaElméleti alapok a tanitás tanulásához. Budapest, Nemzeti Tankönyvkiadó. https://www. tankonyvtar.hu/hu/tartalom/tamop425/2011_0001_519_42498_2/ch01.html

Richardson, W. (1996) The Role of Attitude and Beliefs in Learning to Teach. In: J. Sikula (ed.) Handbook of Research on Teaching Education. Second edition. New York, MacMillan. pp. 102-119.

Thompson, L. K. (2007) Considering Beliefs in Learning to Teach Music. Music Educators Journal, Vol. 93. No. 3. pp. 30-35.

Vartuli, S. (2005) Beliefs: The Heart of Teaching. Young Children, Vol. 60. No. 5. pp. $76-86$. 